\title{
Mielenkiintoinen perusteos yrittäjyyskasvatuksesta
}

Kari Ristimäki (2004). Yrittäjyyskasvatus. Yrityssanomat Oy. 158s.

$\mathrm{V}$ anhasen II hallituksen hallitusohjelmassa, niin kuin edellisessäkin, oppilaitoksilta edellytetään yrittäjyyskasvatuksen opettamista. Usein opettajat mieltävät yrittäjyyskasvatuksen erilliseksi oppiaineeksi, jonka opettaminen kuuluu siihen erikoistuneisiin oppilaitoksiin. Toiset taas kuvittelevat, että heidän opettamastaan oppiaineesta täytyisi karsia jotain pois, jotta yrittäjyyskasvatus mahtuisi tilalle. Näinhän asia ei ole, sillä Ristimäen kirjaa lainaten "yrittäjyyskasvatus on suurelta osaltaan kaikkia oppiaineita koskeva opetuksen metodologinen kysymys” (s.115). Kun tämän ajatuksen on saanut sisäistettyä, tulee tarve hankkia lisää tietoa yrittäjyyskasvatuksesta. Kari Ristimäki on vastannut tähän haasteeseen ja kirjoittanut yrittäjyyskasvatuksesta selkeän perusteoksen. Hän on jättänyt kirjastaan lähdeviitteet pois, mikä helpottaa huomattavasti sen luettavuutta. Kirjan lopusta löytyy kuitenkin kirjallisuusluettelo ja useiden kappaleiden lopussa on mainittu teoksia, joihin tutustumalla lukija saa lisätietoa kulloinkin käsittelyssä olevasta aiheesta. Kirjoittaja on pitänyt lupaustensa mukaisesti kirjan punaisena lankana kysymystä, "miten koulu yleisesti ja opettaja yksityisesti voivat edistää ja kehittää omaa toimintaansa niin, että yrittäjyyskasvatuksen tavoitteet voivat toteutua?” (s.9)

Kirjan alkuosassa selvitetään käsitteenmäärittelyn taustoja ja problematiikkaa sekä yrittäjyyskasvatuksen tarvetta. Yrittäjyyskasvatuksen metodologisten kysymysten antoisan selvittelyn jälkeen pohditaan, miten koulu voi auttaa identifioitumista yrittäjyyteen. Oppilaitosten ja yrityselämän yhteistyötä on käsitelty monipuolisesti omassa luvussaan. Lopuksi kirjoittaja valottaa lukijalle yrittäjyyskasvatusta ja sen sisältöä yksittäisen opettajan näkökulmasta ja viimeiseksi pohditaan koko oppilaitosorganisaatiota ja sen luomaa toimintaympäristöä yrittäjyyskasvatukselle.

Lukija, joka hakee selkeää käsitteenmäärittelyä yrittäjyyskasvatukselle, pettyy. Yrittäjyyskasvatusta on erittäin vaikea määritellä ytimekkäästi. Ristimäen mukaan se on osittain jopa mahdotonta. Tämän kirjan kirjoittaja esittää ansiokkaasti niitä syitä miksi näin on. Kirjoittajan tarkoituksena onkin "tarjota lukijalle mahdollisuuksia perustellusti rakentaa omaan käsitystään yrittäjyyskasvatuksesta” (s.14). Tässä tehtävässä kirja toimii erinomaisesti.

Karkeasti ottaen yrittäjyyskasvatuksen tavoitteet voidaan jakaa kahteen osaan: ensimmäinen tarkoitus on edistää opiskelijoiden yrittäjämäistä toimintaa (sisäinen yrittäjyys) ja toinen tavoite on tuoda yrittäjyys esiin varteenotettavana ammatinvalintäjyys). Kirjoittaja nostaa esiin kolme yrittäjyyden funktiota: innovatiivisuus, riski ja sen hallinnan vaihtoehtona (ulkoinen yrit- ta sekä katalysaattorina toimiminen. Näitä funktioita käsitellään Peter Schumpeterin ja Peter Druckerin teosten valossa ja jokaisesta funktiosta esitellään yksi käytännön esimerkki.

Ristimäki toteaa, että yrittäjyyskasvatuksen tarve juuri 1990-luvulla ei liene sattumaa. Kirjassa pohditaan Alvin Tofflerin 1980 ilmestyneeseen teokseen nojautuen, miten taloudellinen kehitys maatalous-, teollistumis- ja tietoaaltoineen on vaikuttanut yrittäjyyteen ja yrittäjyyskasvatuksen tarpeeseen.

Yrittäjyyden asemaa tarkastellaan organisaatio- ja johtamisteorioista käsin päätyen oppivan organisaation ideaan. Nykyisen tietoaallon ajan talous kulminoituu neljään tekijään. Toiminta perustuu innovatiivisuuteen ja se edellyttää oppimista sekä yksilöltä että organisaatiolta. Kolmanneksi organisaatioissa nousee esiin yrittäjyys ja yrittäjämäinen toiminta. Tällaisia yrittäjämäisiä organisaatioita kutsutaan oppiviksi organisaatioiksi. Tiimiytyminen on neljäs tekijä, joka kytkee edelliset yhteen. Tämä kaikki tuo suuren haasteen opetuksen ja koko oppilaitoksen kehittämiselle.

Miten oppilaitos voi edistää yrittäjyyttä

Mielestäni kirjan antoisimmassa osiossa paneudutaan siihen, miten oppilaitos voi olla edesauttamassa yksilön toimintaa yrittäjyyttä edellyttävässä ympäristössä. Ristimäki esittelee vuonna 1998 opettajien keskuudessa 
tekemänsä tutkimuksen tuloksia siitä, millaisia ominaisuuksia opettajat näkevät palkansaajan ja yrittäjän tarvitsevan. Lisäksi hän pohtii, miten yrittäjyyskasvatus soveltuu koulutusjärjestelmäämme. Kirjoittaja kyseenalaistaa yrittäjyyskasvatuksen erottelemisen sisäiseen ja ulkoiseen yrittäjyyteen. Tämä on mielenkiintoinen ja tervetullut pohdinta yrittäjyyskasvatuskeskusteluun. Ristimäen mielestä oppilaitoksissa voisi puhua ainoastaan yrittäjyyskasvatuksesta ja yrittäjyyden edistämisestä, ja keskittyä mieluummin pohtimaan, miten voisi edistää yksilön persoonaan liittyviä ominaisuuksia.

Koska kirjoittajan mukaan yrittäjyyden edistäminen on suurelta osin persoonallisuuteen liittyvien ominaisuuksien ja toimintatavan edistämistä, Ristimäki siirtyy tarkastelemaan eri persoonallisuusteorioita. Näitä persoonallisuusteorioiden tarkasteluja varmasti kuka tahansa kouluttaja lukee mielenkiinnolla, olipa sitten kiinnostunut itse yrittäjyyskasvatuksesta tai ei. Tarkastelunsa Ristimäki päättää huikeaan ajatusleikkiin sivuilla 6465. Yrittäjyyden opetuksen metodologisiin kysymyksiin paneudutaan myös Jari-Erik Nurmen ja Katariina Salmela-Aron kehittelemän psykologisten prosessien joukkoa kuvaavan kaavion avulla. Näitä teoreettisia toiminta- ja ajattelustrategioita tarkastellaan käytännön esimerkkien avulla.

\section{Yrittäjäidentiteetti kehittyy}

Vaikka Ristimäki kyseenalaistaakin erottelun sisäiseen ja ulkoiseen yrittäjyyteen, on ulkoista yrittäjyyttä käsitelty kahden lu- vun verran. Kirjoittaja esittelee James Marcian mallin, joka kytkee identiteetin kehityksen erityisesti nuoren elämänkulun kannalta tärkeisiin valintoihin. Tämän jälkeen Ristimäki tarkastelee yrittäjyyteen liittyvien ammattiorientaatioiden jakoperusteita hänen oman tutkimuksen avulla. Siinä on analysoitu 262 opiskelijan omaelämänkerrallisen aineiston avulla yrittäjyyteen liittyvää identiteettiä ja sen kehitystä. Identifioitumista pohditaan sukupuoli- ja ikäjakauman näkökulmasta. Karkeasti tulkiten miehet ja yrittäjien lapset identifioituvat paremmin kuin naiset ja palkkatyötä tekevien vanhempien lapset yrittäjiksi. Iälläkin näytti aluksi olevan merkitystä, mutta tarkemman analyysin jälkeen Ristimäki päätyy toteamaan, ettei tämän tutkimuksen perusteella yhteyttä löydy. Yrittäjyysvalinnan osatekijöistä kirjoittaja on tehnyt graafisen esityksen, jota avataan lukijalle ansiokkaasti tutkimusaineistosta esiin tulleiden käytännön esimerkkien avulla. Lisäksi kirjoittaja esittelee lukijalle helposti avautuvan, erilaisiin oppilaitoksiin sopivan liikeideamallin.

Koulutuksen haasteeksi Ristimäki näkee erityisesti niiden opiskelijoiden auttamisen, joilla ei perhetaustan kautta ole mahdollisuutta tutustua yrittäjyyteen. Lääkkeeksi tähän hän ehdottaa oppilaitoksissa jo toteutettavat yritys-oppilaitos-yhteistyöt ja työharjoittelut. Yritysmaailman ja oppilaitoksen välinen yhteistyö sekä opiskelijan tutustuminen työelämään onkin saanut kirjaan oman lukunsa. Aihetta on käsitelty monipuolisesti ja selkeästi. Kirjoittaja esittää asiantuntevasti yhteistyön hyödyt eri osapuolille: yritykselle, oppilaitokselle, opettajalle ja opiskelijalle sekä pohtii miten yhteistoimintaa tulisi kehittää. Oppilaitoksen yritysmaailmaan suuntautuvat yhteistyökuviot eivät kuitenkaan yksin riitä, vaan tarvitaan koko oppilaitosorganisaation toimintakulttuurin muuttumista yrittäjämäiseksi. Siinäpä kaikille erilaisissa oppilaitoksissa toimiville riittääkin haastetta.

\section{Opettajien asenteita ja arvoja selvitetty}

Yrittäjyyskasvatusta yksittäisen opettajan näkökulmasta käsittelevä luku on mielenkiintoinen, mutta mielestäni kirjan haurain osio. Kirjoittaja esittelee tutkimuksensa tuloksia opettajien arvoista ja asenteista yrittäjyyteen ja yrittäjyyskasvatukseen. Opettajana ja opettajankouluttajana jäin kaipaamaan monipuolista ja konkreettista pohdintaa nimenomaan oman opetuksen suunnittelun ja toteutuksen tueksi. Yrittäjyyskasvatuksen sisältöä Ristimäki hahmottaa Jukka Vesalaisen mallin mukaisesti neljälle osa-alueelle: makroulottuvuuteen, liiketoiminnalliseen-, organisaatio- ja yksilöulottuvuuteen. Tätä nelikenttää mukailevan, opettajien keskuudessa suoritetun tutkimuksen tulosten valossa kirjoittaja nostaa esiin kaksi huomionarvoista seikkaa, joista mielestäni oppilaitosten johdon olisi syytä olla kiinnostuneita. Ensimmäinen on opettajien yrittäjyyden ja yrityselämän omakohtainen tuntemus, jota voi edistää esimerkiksi opettajan työelämään tutustumisen avulla. Harvalla opettajalla on riittävästi arvokasta työkokemusta liike-elämän palveluksessa tai se kenties on vanhentunutta. Toiseksi hyvällä täydennyskoulutuksella voi luoda parempia edellytyksiä opettajan yrittäjyyskas- 
vatuksen harjoittamiselle.

Kirjan viimeinen luku on omistettu koko oppilaitosorganisaation ja -instituution luomalle yrittäjyyskasvatuksen toimintaympäristön pohdinnalle. Yrittäjyyskasvatuksen toteuttamisen kehityksen Ristimäki kuvaa asettuvan neljälle eri tasolle. Käytännön esimerkkinä lapualainen luokanopettaja, KM Teija Karvonen kertoo mukaansatempaavalla tyylillään omista käytännön yrittäjyyskasvattajan kokemuk- sistaan alkaen 1990-luvun alusta. Seuraavaksi kirjoittaja pohtii miten oppilaitoksen muuttuminen ja muuttaminen edesauttavat yrittäjyyskasvatuksellisen toimintakulttuurin luomisessa. Lopuksi Ristimäki ottaa esille terminologiakeskustelun, jota opettajien keskuudessa käydään, tai ainakin käytiin vielä vähän aikaa sitten. Yrittäjyyskasvatukselle kaivattiin uutta termiä, esimerkiksi yrittävyys. Kirjoittaja kuitenkin ilmaisee selkeästi oman mie- lipiteensä siitä, että Suomessa termiä yrittäjyyskasvatus tarvitaan juuri tässä muodossa.

Tämä asiantunteva kirja on kirjoitettu jo vuonna 2004, mutta minä löysin sen vasta viime talvena. Toivon sen yhä löytävän uusia lukijoita erilaisissa oppilaitoksissa työskentelevien keskuudesta. Mielenkiintoisia lukuhetkiä!

\section{Anne Tiikkala}

